\title{
THE DELUTION OF A MAN WHO IS NOT CONSIDERED AS A BELOVED ONE TO HIS LOVER IN JEAOLUS SONG'S BY LABRINTH
}

\author{
Priyoto \\ Sekolah Tinggi Bahasa Asing Pertiwi \\ Email: pnrgku@gmail.com \\ Ikbal Ramadhan \\ Sekolah Tinggi Bahasa Asing Pertiwi \\ ikbal.ramadhan30@yahoo.co.id
}

Priyoto and Ikbal Ramadhan. (2020). An analysis of morphological and syntactical errors in recount text. Journal of English Language and literature, 5(1), 19-32. DOI 10.37110/jell.v5i01.92

Received: 19-12-2020

Accepted: 01-02-2020

Published:01-03-2020

\begin{abstract}
The objective of this study are: 1) to analyze the literal meaning and the figurative language in the lyrics of the jealous song; 2) to know the reflection of having excessive delusion based on the lyrics; and 3) to describe the emotional feelings of the speaker that implied on the lyric jealous song. This song tells about a man that once had a girlfriend but he lost her and cannot stand the fact that she is giving her love to someone else. He also feels jealous of all things around her, because they are closer than he could ever be. To analyze this song the writer uses psychological approach. In the society there is someone who has the same feeling or experience that is implied from this song, and gives influence to people's mindset. The mindset is directed with the intension that the people get the impression after listening and reading the lyrics. This song gives reaction delusion to be self defense mechanism and the anxiety disorder. Denial, compensation, displacement, identification, repression and emotional quantity become factors which give contribution to Labrinth in implied his delusion.
\end{abstract}

Key words: literal meaning; figurative language; lyrics; excessive delusion

\section{INTRODUCTION}

A song broadly is a single work of music that is typically intended to be sung by the human voice with distinct and fixed pitches and patterns using sound and silence and a variety of forms that often include the repetition of section written words. Created specifically for music, music is specifically created are called lyrics. Language the song lyric is not so much different languages poetry. The lyrics are poetry that is sung. Emotive from of expression is manifested in sounds and words. The lyrics of the song as one of the building blocks in song or music can be categorized as a poem in a literary work. It can be seen from the similarity of structure and density the message.

Through the lyrics composer wanted to convey the message which is an expression of them based on the experiences of phenomena that occur in the world about which they interact in it. Song itself as some genres. The genres of the songs grouped on the basis of types and kind of music according to the characteristics and similarities that exist. The character are divided into genres of music included the tone, rhythm, music engineering, context the tempo up to geographical origin. The kinds of song are: $R \& B$, pop, jazz, blues, rock and many more.

The aim of this research is to know the figurative language, to understand the reflection of having delusion in life and third is to describe the delusion in life .

Literature Review

\section{REVIEW OF LITERATURE}

\section{Figurative Language}


According to literary device.com figurative language uses figures of speech to be more effective, persuasive and impactful. Figurative speech means that figurative language has different and simply way to express an otherwise boring statement and enables us to explore language in new become interesting ways to understand. Figurative language such as metaphors, similes and allusions go beyond the literal meanings of the words to give readers new insight on the other hand alliteration, imageries and onomatopoeias are figurative devices that appeal to the senses of the readers. According to Groys Kerraft, Figurative language or style is a way of showing mind through a special language that shows the soul and the characteristics of the writer (language of user), (Groys 2009:113).

It can be inferred that "figurative language is style or the way of giving expression through a special language which shows the soul and the writer personality (language of user). A good language style has to certain three elements, there are: sincerity, respectful, and attractive, (Groys 2009: 113).There is many types of figurative language such as: metaphor, simile, symbol, hyperbole, irony, etc. In general figurative language is differentiated into four groups, they are: confirmation, comparison, opposition and allusion.

From the explanation above, it is considered that figurative language deals with language which uses figure of speech and language cannot be taken literary only and it is used to express the inner feeling of the writer.

There are many types of figurative language:

1) Metaphor

A metaphor compares two unlike things that have something in common. "The skies of his future began to darken," darkness is a threat therefore; this implies that the coming times are going to be hard for him. In this case you would be making a metaphor - a form comparison that directly compares two unlike things. A metaphor wastes no time in getting to the point.

2) Simile

If you said, "her face is like cotton", you would be making a simile - a form of comparison in which one thing is compared to another unlike thing by using specific word of comparison like like, as, and resembles. Simile is a figure of speech, which directly compares two things. Although similes and metaphors are similar, similes explicitly use connecting words. "The simile set two ideas side by side; in the metaphor they become superimposed. It would seem natural to think that simile, being simples, is older." (F.L.Lucas, Syle. Macmilan, 1955).

3) Symbol

A thing could be an object, person, situation, or action that stands for something else more abstract. For example: from the lyrics of song that the writer chooses, "I'm jealous of the rain," the rain here as symbol for a person. According to Scott Plunkett, "symbolic interactions are the way we learn to interpret and give meaning to the world through our interactions with others". These descriptions believe and meanings are nothing. But interpretation is given by the people. The theory suggests that society is based on the interpretations of the people, the people interpret each other's behavior and a social bond is the created which is grounded. In these interpretations are called "definition of the situation" because they just define the situation.

4) Personification

One of the most familiar kinds in comparison is personification. A figure of speech in which a thing, an idea or an animal is given human attributes. The non - human object are portrayed in such a way that we feel they have the ability to act like human beings. For example: "I'm jealous of the wind that ripples through your clothes," we are giving the wind the ability to ripples which is a human or an animal ability. According to Richard Grill (1985:593) said that the point of the personification is to express the abstract ideas to inanimate objects, or aspect of nature are describe as if it were human. Personification is 
p-ISSN 2540-8216, e-ISSN 2654-3745

https://journal.stibaiec-jakarta/ojs/index.php/jell

containing an equation, as inanimate objects that acts like a human or dispositive human. Inconclusive that personification has an effect to describe the imagination of the readers. Because, as by level thing non human, as the empathy of the reader is easy to inflected, because the reader feel familiar with the things to describe or conveyed a lyrics in this song.

5) Hyperbole

The great exaggeration used to emphasize a point, and is used for expressive or comic effect. A hyperbole is not to be taken literally. Hyperbole can be found in literature and oral communication they would not be used in non functional works. The use of hyperboles generally relays feelings or emotions from the speaker, or from those who the speaker may talk about. Hyperbole can be used in a form of humour, excitement, distress and many other emotions, all depending on the context in which the speaker uses it. According to Wren \& Martin (1981:491) in hyperbole a statement is made emphatic by overstatement. It means that some words which are used in a novel are overstatement from true meaning. For example: she is as heavy as an elephant. It means that the girl is heavy or big as an elephant.

6) Irony

A figure of speech in which words are used in such a way that their intended meaning is different from the actual meaning of the words. It may also be a situation that may end up in quite a different way than what is generally anticipated. In simple words, it is a difference between the appearance and the reality. There are two types of irony, verbal irony and dramatic irony. Verbal irony is a figure of speech when an expression used in the opposite of the thought in the speaker's mind, thus conveying a meaning that contradicts the literal definition. Dramatic irony is a literary or theatrical device of having a character utter word which the reader or audience understands to have a different meaning. Irony of situation occurs which is quite the reverse of what one might have expected.

\section{Self Defense Mechanism}

When inner conflict is acute and anxiety threatens the defense mechanism tries to reduce the anxiety by means of irrational techniques known as unconscious defense mechanism. Among the most common defense mechanism are Compensation, Denial, Displacement, Identification, Projection, Introjection, Rationalization, Reaction Formation, Regression, Repression, Ritual and Undoing, sublimation.

Denial is the refusal to accept reality or fact, acting as if a painful even, thoughts or feeling did not exists. It is considered one of the most primitive of the defense mechanism because it is characteristics of early childhood development. Many people use denial in their everyday lives to avoid dealing with painful feelings or area of their life, they do not wish to admit. For instance, a person is a functioning alcoholic with often simply deny they have a drinking problem, pointing to how well they function in their job and relationship.

Regression is the reversion to an earlier stage of development in the face of unacceptable thoughts or impulses or the returning to an earlier time in your life. When you were not so threatened with becoming negative self-concepts you return to thoughts, feelings and behaviors of an earlier developmental stage in order to identify yourself as you used to back then.

Projection is the misattribution of a person undesired thoughts, feeling or impulses onto other person who does not have those thoughts, feeling or impulses. Projection is used especially when the thoughts are considered unacceptable for the person to express or they feel completely ill at ease with having them. Projection can be attribution to others of your own negative self-concepts, this occurs when you want to avoid facing negative self-concepts about your behaviors or intensions and you do so by seeing them in other people instead.

Reaction formation is the converting of unwanted or dangerous thoughts or felling, impulses into their opposite, It's believed that reaction formation develops as a way to cope with the pressure and stress caused by the original feeling that they have identified as being bad and with the possibility of their true feelings or desires being discovered. It's 
important to point out that this behavior is not the same as lying or being deceitful. In cases of reaction formation, the feelings associated with the perceived negative behavior are so strong and anxiety-provoking that the reaction can be compulsive, which means that the urge to react is too strong to be controlled. Moreover, because of their inflexibility, they may feel compelled to behave this way all of the time in order to ensure that the truth is never revealed. So, reaction formation is one of types of defense mechanism in which a person acts in the exact opposite manners to his own disturbing or socially unacceptable thoughts or emotions. By using reaction formation, ones self-identity remains "safe" as the ego is kept in ignorance of the person true motives. For example, a man who fears that he is falling in love with his new girlfriend begins to pick fights and lash out at her in anger. Behavior due to reaction formulation is often extremely exaggerated, compulsive and inflexible. These behaviors do not vary due to changes in emotions as do natural behaviors.

Sublimation is simply to channeling of unacceptable impulse, thoughts and emotions into more acceptable ones. In which a person tries to 'undo' an unhealthy, destructive or otherwise threatening thought or action by engaging in contrary behavior. Sublimation is a mature type of defense mechanism, where socially unacceptable impulse or idealizations are unconsciously transformed into socially acceptable actions or behavior, possibly resulting in a long term conversion of the initial impulse. According to Sigmund Freud (1930), "an especially conspicuous feature of cultural development, it is what makes it possible for higher psychical activities, artistic or ideological, to play such an important part in civilized life". Sublimation was sign of maturity and civilization, allowing people to function normally in culturally acceptable ways. He defined sublimation as the process of deflecting sexual instinct into acts of higher social evaluation.
Ritual and Undoing is attempt to take back unconscious behavior or thoughts that is unacceptable hurtful. In essence, it involves feeling guilty and trying to do something to undo the harm that may have been inflicted. It is trying to reverse or undo a feeling by acting in some opposite or compensatory manner. Undoing is which a person attempts to alone or erase some negative action, impulse or idea by performing behaviors that are contrary or opposite to the undesirable one, it is an attempt to undo a negative or undesirable behavior by doing the opposite. Undoing is essentially negating a previous behavior thought viewed negatively by performing a behavior contrary to it.

Compensation is a process of psychologically counter balancing perceived weakness by emphasizing strength in other areas. Alfred alder observed that much of human life is devoted to compensating for whatever we think are our weaknesses. Sometimes we try to improve on whatever we are weak in, the most famous example being Demosthenes becoming a great speaker. Sometimes people recognize a weakness in one area, but try to excel in another. Some examples of this can be seen in average students becoming outstanding athletes, and students who are physically not very attractive becoming great scholars. These are healthy way to handle the anxiety of feeling inferior or inadequate. There are, however, unhealthy ways to compensate, such as a person feeling unloved becoming promiscuous, substituting quantity for quality.

Displacement is when you express feeling to a substitute target, because you are unwilling to express them to the real target. The feelings expressed to the substitute target are based on your negative self-concepts about the real target and yourself in relation to the real target. That is, you think poorly of someone and of yourself in relation to them.

Identification as a defense mechanism is the identification of yourself with cause, groups, heroes, leaders, movie stars, organization, religions, sports stars, or 
whatever you perceive as being good selfconcepts or self-images. This is a way to think of you as good self-concepts or image.

Introjection is the acceptance of the standards of others to avoid being related as negative self-concepts by their standards. For example, you may uncritically accept the standards of your government or religion in order to be accepted as good self-concepts by them. Introjection can be considered as the extreme case of conformity, because introjection involves conform your beliefs as well as your behaviors.

Rationalization is the process of explaining why, this time, you do not have to be judged as negative self-concepts because of your behaviors or intensions. That is, you justify and excuse your misdeeds or mistakes with reasons that are circumstantial at best and unfounded at worst. Rationalization can also take the opposite tack or what is sometimes referring as response.

Repression is the unconscious and seemingly involuntary removal from awareness of the negative self-concepts that your ego finds too painful to tolerate. Repression is a choice, but a choice that we choose to remain unaware of as part of the defense of repression.

\section{Anxiety disorder}

Anxiety disorders are different, though. They are a group of mental illness, and they cause can keep you carrying on with your life normally. For people who have one, worry and fear are constant and overwhelming, and can be disabling. The characterized by significant feelings of anxiety and fear. Anxiety is worry about future events and fear is a reaction to current events. These feelings may cause physical symptoms, such as fast heart rate and shakiness. There are a number of anxiety disorders: including generalized anxiety disorder, specific phobia, social anxiety disorder, separation anxiety disorder, agrophobia, panic disorder, and selective mutism.

Generalized anxiety disorder is the characterized by excessive worry about variety of topics. According to the diagnostics and statistical manual of mental disorders fourth edition, text revision (DSM-VI-TR; APA, 2000) is excessive worry occurring on more days than not, about a number of different topics. Worry must persist for at least 6 months, and can involve a wide variety of topics, such as finances, health, safety, and minor matters. The worry is often unrealistic or out of proportion for the situation. Daily life becomes a constant state of worry, fear, and dread. Eventually, the anxiety so dominates the person's thinking that it interferes with daily functioning, including work, school, social activities and relationship.

Specific phobia is any kind of anxiety disorder that amounts to an unreasonable or irrational fear related to exposure to specific objects or situations. The effected person tends to avoid contact with the objects or situation and in severe cases, any mention or depiction of them. Having phobias can disrupt daily routines, limit work efficiency, reduce self-esteem, and place a strain on relationship because people will do whatever they can to avoid the uncomfortable and often-terrifying feelings of phobic anxiety.

Social anxiety disorder is the anxiety can interfere significantly with daily routines, occupational performance, or social life, making it difficult to complete school, interview and get a job and have friendships and romantic relationship. Social anxiety disorder usually begins in childhood or adolescence, and children are prone to clinging behavior, tantrums, and even mutism. People with social anxiety typically know that their anxiety is irrational, is not based on fact, and does not make rational sense. People with social anxiety realize that it is anxiety and fear that they are experiencing.

Separation anxiety disorder is a psychological condition in which an individual has excessive anxiety regarding separation from places or from people to whom the individual has a strong emotional attachment. In children, the strong emotional attachment is likely to a parent; in adult separation anxiety disorder, the attachment might be too a spouse or friend.

Agrophobia or agoraphobia is derived from Greek words literary meaning "fear of the marketplace." The term is used to describe an irrational and often disabling fear of being out in public. The defining of agrophobia is anxiety about being in place from which escape might be embarrassing or difficult, or in help might be unavailable. The person suffering from agrophobia usually avoids the anxiety-provoking situation and may become totally housebound.

Panic disorder is a chronic, debilitating condition that can have a devastating impact on a 
person's family, work, and social life. The characterized of the panic disorder by recurrent unexpected panic attacks. Panic attacks are sudden periods of intense fear that may include palpitations, palpitation are perceived abnormality of the heartbeat, sweating, shaking, shortness of breath, numbness, or a feeling that something really bad is going to happen.

Selective mutism is anxiety disorder in which a person who is normally capable of speech cannot speak in specific situation or to specific people. Selective mutism usually co-exists with shyness or social anxiety. People with selective mutism stay silent even when the consequences of their silence include shame, social ostracism or even punishment. Selective mutism usually starts in early childhood, between the ages of two and four.

\section{METHOD}

In this thesis, the writer would like to use the qualitative research method to analyze and describe the reflection of disillusion based on the lyrics. The writer analyzes the song and presents it in the form of article. Writer tries to describe the meaning which is found in the words of that song.

\section{FINDING AND DISCUSSION \\ Finding}

In this chapter the writer would like to analyze the literal and figurative meaning of jealous song. In analyzing the literal meaning of the song is aimed to know in depth the meaning of the lyrics and to avoid misinterpretation of the song. In analyzing the figurative meaning of the song is to know the metaphors of the words by using, because the point elsewhere for the true meaning or the expression of the lyrics because the speaker express an idea without having to be literal. Literal means taking words in usual or most basic sense without metaphor or allegory.

This song consists of 38 lines and 10 stanzas. The writer present his analyze stanza by stanza and each stanza would be analyzed line by line. The writer explains all of those lines of the lyrics and he is able to re-explain the repetition of the sentences since it gives the same sense and meaning, but different way of the explanation in each line, he would elaborate the meaning of the lyrics.

\section{First Stanza}

(1) I'mjealous of the rain

\section{(2) That falls upon your skin}

I' $\mathrm{m}$ in this line refer to the speaker which jealous of the rain, rain in line refers to someone that the speaker threats like for the person who closes with the women. The speaker assumes to everyone who take the jealous which is that unpleasant emotion which describe that the speaker still want to be near by his loverjust like "rain"can do. Your refer to the speaker lover that he cannot to be closed. The word falls upon your skin refer to the other person who can touching the women and getting close with her. I'm jealous is the feeling of the speaker, here the speaker imagine that he feels like this because he cannot to be close even he is near by the women, he can saying or doing anything just feeling that he want to do something.

(3) It's closer than my hands have been

(4) I'm jealous of the rain

Then the third line the speaker says, "it's (it is) closer than my hands have been, I'm jealous of the rain". The third line my hands refers to the speaker it means willing as a man who loves with someone he want to be closer with his lover but he can not do anything what he wanted. The word rain means some body else or the other man around of her who can be closer with her than his self. Because jealous are something that easily to show the unpleasant emotion that you feel when you think someone tries to take what is yours because it can make people obsessed with how they compare to others always trying to beat their rival. The speaker describe that a jealous is like people feel inadequate to do something with what he wanted.

Rain is the symbol of the other person who takes close with the speaker lover. Rain has acted as a symbol of numerous things ranging on a wide scale of a good and bad even since symbolism has ever been around. Rain can stand fro so many things that it is impossible to choose which are without the context of the story. In the lyrics the speaker give 11 repetition of the words I'm jealous, in 1, 4, 5, 8, 16, 18, 21,24 .

\section{Second Stanza}

(5) I'mjealous of the wind

(6) That ripples through your clothes

Next the speaker says, "I'm jealous of the wind that ripples through your clothes". In this line refers to the speakers feeling, I' $m$ refer to the speaker like the first stanza the speaker gives metaphors to describe his feeling. The word wind is the flow of gases; wind is mostly the movement of air or particles from the sun through space. The wind usually invisible about someone else is closer with his lover. The word ripples refers to the third person who are close with the speaker lover. The writer try to assumes that ripples is something the third person can do, to be a man who can ripped or take over his place in side of the women. 
Journal of English Language and literature Volume 5, Issue 1,March 2020

(7) It's closer than your shadow

(8) Oh, I'm jealous of the wind, cause

Then the speaker says, 'It's (it is) closer than my shadow oh, I'm jealous of the wind, cause". The word shadow is a dark area where light from a light source is blocked by an opaque object it is refers to the speaker as her lover but he can be close with his lover. So the writer assumes that is jealous with someone else who are very closed than him as a man who is standing beside her. The speaker imagine that he want to be close even she is shadow. The words I'm jealous it is repetition from the first stanza tells about the speaker feeling.

Shadow as a symbol is person who consists of all of the characteristics, lesson, dreams, and ideals. Which is we have chosen to not incorporate into our everyday self. Shadow is personal receptacle for all of the things we do not wish to bring into our life. The writer assumes that the shadow in this line is the other person who is always beside her in everywhere he women stand in.

\section{Third Stanza}

(9) I wished you the best of

(10) All this world could give

After that the speaker says, "I wished you the best of, all this word could give". I refer to the speaker. The word wished is a hope or desire for something. In this line the speaker hopes that his lover can get the best in her lives. The word all refers to his lover with everything she does and wants she can get the best, also refers to any other lovers she might find even though he is in pieces he still cares for the woman that broke his heart because he can not to be close with her. So he wished that she can get anything the best for her lives. The world could give is a metaphors that imagine she can get anything by the world.

(11) And I told you when you left me

(12) There's nothing to forgive

In this part the speaker says, "And I told you when you left me, there's (there is) nothing to forgive." The word I refer to the speaker, he assumes that there is nothing to forgive for him even the women go left him for something he honestly forgives her. The word you refer to the speaker lover. The writer assumes that his lover was the one who broke up with him but he forgave her and he let her go even when he did not want her to leave. The speaker just known that love feeling is cannot to be forced, he know that just have an feeling and forgiving he can give when he get the women is left him.

\section{d) Fourth Stanza}

(13) But I always thought you'd come back, tell me all you found was
p-ISSN 2540-8216, e-ISSN 2654-3745

https://journal.stibaiec-jakarta/ojs/index.php/jell

(14) Heartbreak and Misery

In this part the speaker says, "But I always thought you come back tell me all you found was, heartbreak and misery'. The word I refer to the speaker, he thought that the women will be come back with him and the he opened by his self to the women, whatever the women got just tell everything with him. The speaker expected that his lover would miss with him but she found an experience about the heartbreaker or the feelings of great sadness or disappointment. The word you refer to the women. The writer thinks that his lover was the one who broke up with him but he forgave her and he let her go even when he did not want her to leave.

(15) It's hard for me to say, I'm jealous of the way

(16) You're happy without me

Next line I' $m$ referring to the speaker, the speaker is jealous of a lot of things but there is nothing he is more jealous than his lover. Being able to move on, while he just cannot. He jealous that someone else has he is dream girl he is just jealous that he is not in her life he sees her doing fine without him. He is jealous that she could find happiness with someone that was not him. He is jealous that he could not make her as happy as someone else could.

In this line the writer take some irony of the lyric, you're happy without me here the speaker avoid what he wanted. The speaker tries to avoid because the women has got the experience that make her fells happiness. But, the speaker cannot say anything to show that he hurts with the experience she got.

\section{Fifth Stanzas}

(17) I'm jealous of the night

(18) That I don't spend with you

I'm jealous it is repetition from the first line. I'm referring to the speaker who is jealous with the night. The night refers to the situation of the speaker. The night means at one time in the situation. The writer thinks of all the nights that she is stand with someone else but not him. He could understand the situation between him and her. You refer to the speaker lover that he cannot spend all time. The night is the time or the situation when the speaker lovers spend time with another person but not the speaker.

(19) I'm wondering who you lay next to

(20) Oh, I'm jealous of the nights

Next, I'm referring to the speaker, 'I'm wondering who you lay next to, oh I'm jealous of the nights." In this line the speaker imagine about someone who stands with her lover now and the speaker wishes that he was there place instead. The speaker jealous with the situation that he can be spend time his lover and the other man. Night can be 
symbolism of the complete loss of hope that is falls the speaker it is also represent the loss of faith the feeling on the lyrics. The speaker says I'm wondering it could be the speaker imagination when he cannot spend time with her lover.

The night is symbol of the situation at one time when the man complete loss of the hopes and also representation of the loss of faith the feeling.

\section{Sixth Stanza}

(21) I'm jealous of the love

(22) Love that was in here

In this part the speaker says, "I'm jealous of the love." I'm referring to the speaker. The writer assumes that the speaker jealous of the love that is no longer there. The speaker jealous of the love that his lover once had for him, she is now giving to someone else. Love can be an intense feeling of deep affection or feel deep romantic or sexual attachment to (someone). Love is completely unconditional, it means love has no condition when we truly love someone we cannot stop loving them, or regardless of what they do or say.

(23) Gone for someone else to share

(24) Oh, I'm jealous of the love, cause

The speaker says, "Gone for someone else to share." In this part someone refers to the other person who closes with the women, and the other person is the place for the women to share. In this line the speaker imagine the women gone away to look for another to share everything in here is love. According to urban dictionary.com, love is an incredibly powerful word; the writer assumes that in this line is unconditional love affection with no limits or conditions, in completely loving someone. It is when you trust the other with your life and you would anything for each other. Love can make you do anything and sacrifice for what will be better in the end. Love is intense and passionate. I'm jealous it is repetition feeling from the first line.

\section{Seventh Stanza}

(25) I wished you the best of

(26) All this world could give

In this line repetition from line nine (9) here the speaker says, "I wished you the best of, all this word could give". I refer to the speaker. The speaker is very hope that the women could get the best from the world. The word wished is a hope or desire for something. In this line the speaker hopes that his lover can get the best in her lives. The word all refers to his lover with everything she does and wants she can get the best, also refers to any other lovers she might find even though he is in pieces he still cares for the woman that broke his heart because he can not to be close with her. So he wished that she can get anything the best for her lives.

(27) And I told you when you left me

(28) There's nothing to forgive

This part is the repetition from the line above, here the speaker says, "And I told you when you left me, there's (there is) nothing to forgive." The word I refer to the speaker, he assumes that there is nothing to forgive for him even the women go left him for something he honestly forgives her. The word you refer to the speaker lover. The writer assumes that his lover was the one who broke up with him but he forgave her and he let her go even when he did not want her to leave.

\section{Eight Stanza}

(29) But I always thought you'd come back, tell me all you found was

(30) Heartbreak and Misery

In this part the speaker says, "But Ialways thought you come back tell me all you found was, heartbreak and misery". The word I refer to the speaker and you refers to his lover. The writer thinks that his lover was the one who broke up with him but he forgave her and he let her go even when he did not want her to leave. The speaker expected that his lover would miss with him but she found an experience about the heartbreaker or the feelings of great sadness or disappointment.

(31) It's hard for me to say, I'm jealous of the way

(32) You're happy without me

Next line I'm referring to the speaker, the speaker is jealous of a lot of things but there is nothing he is more jealous than his lover. Being able to move on, while he just cannot. He jealous that someone else has he is dream girl he is just jealous that he is not in her life he sees her doing fine without him. Heis jealous that she could find happiness with someone that was not him. He is jealous that he could not make her as happy as someone else could. These line the speaker hiding about what he feels.

This line implied the irony of the speaker because he cannot say that it is hurt for the speaker which is know the women will be happy and find even though it is not with him.

\section{Ninth Stanzas}

(33) As I sink in the sand

(34) Watch you slip through my hands

In this line the speaker says, "As I sink in the sand." Sand refer to the time, when the speaker watching her slip away from him as he is slowly sinking away further and 
further could be understood as a metaphor for the sands of time. He is stuck in the past, slowly sinking into the sand of time as it rises around him, while she rises above it having moved on. My refer to the speaker who will be there when the women get slip in the way she left from him.

(35) Oh, as I die here another day

(36) Cause all Ido is cry behind this smile

Next, I refer to the speaker. In this line the speaker things look great at his face still smile, but deep inside he is dying without her. Like as he feels empty in his inside everyday withouther, the speakerputs on a fake smile so she can think he is happy withouther but he really cries. Die here refer to the feeling of the speaker when he feel in deep with her and ignore from her it likes everything become nothing and he just trying in case could be smile in front of her.

In this lyric the writer assumes an irony, because the part of the lyrics all I do is cry behind this smile the speaker cannot do anything to show what he feels just shows that he feels fine in front of her.

\section{Tenth Stanzas}

(37) It's hard for me to say, I'm jealous of the way

(38) You'rehappy without me

The last lines, me refer to speaker. "It's (it is) hard for me to say, I'm jealous of the way." In this line the speaker jealous of a lot of things, but there is nothing he is more jealous of than his love being able to move on while he just cannot. Hard refer to the speaker feeling when he want to say that he jealous with a lot of thing, which is everything that the women get from everyone, every situation it is more hard he felt. You refer to the speaker love or the women. In this line the speaker assumes that the women could be happier without me because she gets a lot of things around her. Me refer to the speaker that has ignore that just not with him the women can get the happiness but the world is too can give the happiness for her life.

\section{Discussion}

\section{The Reflection of Having Excessive Delusion and How the Speaker Describe his Emotional Feelings to his Delusion}

The writer analyzes the second problem using the theory of Psychoanalytic theory by Sigmund Freud. Here the writer discusses about Self Defend mechanism which is related to the lyrics and some proof in this song. The writer analyzes the deeper meaning of the song based on psychological approach and the some theories. Jealousy is relates to what their feeling and what kind of the situation of having jealousy. This chapter is continuation of analyzing the problem in chapter III. Then, this is also the last part of analyzing the problem.

\section{The Reflection of Having Excessive Delusion}

In this chapter the writer explains about theory of self defense mechanism by Sigmund freud. Sigismund Schlomo Freud or the people know him as Sigmund Freud was an Austrian neurologist and founder of psychoanalysis, a clinical method for treating psychopathology through dialogue between a patient and psychoanalyst. In creating psychoanalysis, Freud developed therapeutic techniques. He hoped that his research would provide a solid scientific basis for his therapeutic techniques. The goal of Freudian therapy, or psychoanalysis, was to bring repressed thoughts and feeling into consciousness in order to free the patient from suffering repetitive distorted emotions (Ford and Urban, 1965. 109).

According to Discovering Psychology, "an emotion is a complex psychological state that involves three distinct components: a subjective experience, a psychological response, and behavioral or expressive response." These emotions can then be combined in a variety of ways, which are happiness and anticipation might combined to create excitement. Cognitive models propose that cognitive and emotional processes, in the context of anomalies of experience, lead to and maintain delusions (Hockenbury, D. H. \& Hockenbury, S. E. 2007).

The following of self defense mechanism is a partial of 12 type's identifyied by Sigmund Freud, but in this discussion the writer just explains some of types of self defense mechanism based on the lyrics.

\section{1) Compensation}

Compensation is the process of making perceived negative self-concepts by developing positive self-concepts to make up for covers perceived for negative concepts. In other word compensation is strengthen one to hide another.

(1) I'm jealous of the rain,

(2) that falls upon you're (you are) skin In this line rain is threats like for the person who is closes with the women. Here the writer assumes that I'm jealous is feeling of the speaker that he is hiding with others or with the situation of him. Here is the unpleasant emotion which describe that the speaker still 
want to be near by his lover just the others can do by touching the women and getting close with her. Here the speaker cannot say or doing anything just hiding what he feels that want to do something. This is one of types of the compensation which is developing the positive feel from the speaker to cover up the negative feels.

(5) I'm jealous of the wind

(6) that ripples through your clothes

This line the speaker wants to describe more the emotion feeling. The wind describe an invisible about someone else is closes with her. In this line the writer assumes that the third person can do, to be a man can ripped or take over his place in side of the women. Here the speaker still hiding what he feels, because he cannot say anything just imagine that I'm jealous with the other who can take his place even though the third person still mysterious for him.

\section{2) Displacement}

Displacement is the shifting of actions from a desired target to a substitute target when there is some reason why the first target is not permitted or not available. Displacement may involve retaining the action and simply shifting the target of that action. In other word displacement is when you express feeling to a substitute, because you are unwilling to express than to the real.

(3) It's (it is) closer then my hands have been,

(4) I'm jealous of the rain

In this line the speaker tells about displacement of his place. Here the speaker means willing like the other to be close with the women. The writer assumes this line the speaker shows the unpleasant emotion if the speaker hopes what he wanted and what he felt. It is like people feeling inadequate to do something what the speaker wanted.

(19) I'm wondering who you lay next to (20) I'm jealous of the nights

In this line the speaker assumes that he was wondering that the women will stand with another person. The speaker is jealous in this situation when the other person could stand her side. This line is the imagination of the speaker when the time is not his. In this line displacement could implied with the women would lay with the other that is displacement of the speaker.

The writer concludes that the displacement in these lyrics is an action from the desire and the shifting the target of that action. While the speaker has not real in the position he still cares and hopefully for the best thing that the women can get. Displacement is one of the self defense mechanism which is quite satisfactory and workable mechanism for releasing energy more safely.

\section{3) Denial}

Denial is one of the self defense mechanisms which is involves blocking external events from awareness. If some situation is just too much to handle, the person just refuses to experience it. As you might imagine it is one of the dangerous defenses. No one disregards reality and gets away with it for long. In other words denial is the refusal to accept reality or fact, acting as if a painful even, thoughts or feeling did not exists. In which a person is faced with a fact that is too uncomfortable to accept and rejects it instead, insisting that it is not true and despite what may be overwhelming evidence.

(37) It's (it is) hard for me to say, I'm jealous of the way

(38) you're (you are) happy without me

In this line the speaker tells about denial because he tries to hide his sadness with the women that he is jealous of things that around the women. But, there is nothing he is more jealous than his lover. His feeling of jealous that someone else has makes his heart crumbled. So, he hopes the woman that he loves can get happiness with somebody else.

(9) I wished you the best of

(10) all this world could give

This line is related with the denial in self defense mechanism, because here the speaker trying to ignore what is the fact of life. The speaker trying to act he can give anything the best for the women even he in pieces but he still care with her.

(23) Gone for someone else to share, 
(24) I'm jealous of the love

In this line the writer still explains about the denial based on the lyrics. Here the speaker ignores that the women does not need the others to share her love; there is a man who will wait for her just for the love. In this line of the lyrics the speaker wants to show who the best for sharing the love is is, but the speaker just ignores this feeling just because the women share the love.

In short the writer takes conclusion for denial is involving blocking external from the awareness of the speaker in the situation is just too much to handle, the speaker just refuse to experience with what should he does and what should he got.

\section{4) Repression}

Repression is the process of forcing thoughts into the unconsciousness, seemingly unexplainable naivety, memory lapse or lack of awareness of one's own situation and condition, the emotion is conscious, but the idea behind it is absent. In other words, repression is the unconscious and seemingly involuntary removal from awareness of the negative self-concepts.

(13) But I always thought you'd (you would) come back tell me all you found was

In this line the writer give an example of repression based on the lyrics. In this line the speaker open by his self for the women, whatever she got just tells everything with him. The speaker expected about the women would miss him but she found some new experience. In this line unconsciousness about feeling the speaker that she would come back with him.

\section{5) Identification}

Identification is an unconsciousness mental process by which someone makes part of their personality conforms to the personality of another, who serves as a model. Identification has come to refer to principal mode of relating to others and has been integrated in the processes that constitute the psyche. Identification should be distinguished from imitation, which is a voluntary and conscious act. The process whereby the subject assimilates an aspect, property, or attribute of the other and is transformed, wholly or partially, by the model the other provides. It is by means of a series of identifications that the personality is constitute and specified. In other words identification as a defense mechanism is the identification of yourself with causes whatever you perceive as being good self-concept or self image. This is away to think of yourself as good self-concepts or image.

(33) As I sink in the sand,

(34) watch you slip through my hand

In this line the writer assumes that the women will be slip at the time why the writer takes this line to be identification because the speakers imagine that the women will slip through his hands means the speaker will be there at the women need him at the time.

\section{(12) There's (there is) nothing to forgive}

This line still the identification because the speaker assumes that there is nothing to forgive for everything that she does to him. Here identification about the ending of the relationship between he and the women.

\section{The Speaker's Ways to Describes His Emotional Feelings to His Delusion}

In discussing the third problems, the writer explains about the speakers emotional feelings to his delusional disorder. Delusional disorder, previously called paranoid disorder, is a type of serious mental illness called a psychosis. The various type of mental illness and mental health problem, such as anxiety, obsessive compulsive disorder, drug addiction, and personality disorder. In which a person cannot tell what is real from what is imagined. The main feature of this disorder is the presence of delusions, unshakable beliefs in something untrue or not based on reality. People with delusional disorder generally experience non-bizarre delusions, which involve the situation that could occur in real life, such as being followed, poisoned, deceived, conspired against, or loved from a distance. These delusions usually involve the misinterpretation of perceptions of experience. In reality, however, the situation is either not true at all or highly exaggerated. In third problems the writer chooses mental illness anxiety to describe based on the lyrics.

Anxiety feels anxious now and then, it is a normal emotion. It is group of mental illness, and the distress they cause can keep you from carrying on with your life normally. In this discussion the 
writer will describes the speaker emotional feelings based on the lyrics.

\section{a. Generalized anxiety disorder}

Generalized anxiety disorder is characterized by persistent and excessive worry about a number of different things. People with this anxiety may anticipate disaster and may be overly concerned about money, health, family, work, or other issue. In other words generalized anxiety disorder is fears that cannot be controlled.

(27) And I told you when you left me (28) there's (there is) nothing to forgive

In this line the writer takes generalized anxiety disorder because the speaker says, when you left me it is something that the speaker cannot hold it by himself. It is the women want; she wanted to go from him. According to theory about generalized anxiety disorder this line implied it in his lyrics to tell there is something hi cannot handle by himself.

(19) I'm wondering who you lay next to

In this line still implied about generalized anxiety disorder of the speaker. Because in this lyric the speaker tries to show that something he cannot do for himself, it is with who the women will spend the time in some situation. It is a situation that the speaker cannot handle because he cannot always beside the women even though that he wanted to do that action. In this case the speaker worry about with whom the women will spend the time. Actually the speaker wanted but he cannot do anything for doing that.

(23) Gone for someone else to share

This line implies about generalized anxiety disorder too, it because the speaker is still with his worry with the women. In this line the speaker often feel powerless and sometimes he is in the depressed situation this is the case that someone difficult to concentration about anything.

(35) Oh...as I die here another day

(36) cause all I do is cry behind this smile

The writer still take these lyrics relate with the generalized anxiety disorder, because of $a s I$ die it is something that the human cannot control just God knows about that. Here the speaker tries to explain about frustration that the speaker cannot control he just can do what he can do.

In short the writer concludes about the generalized anxiety disorder that is implied in these lyrics. According to Ruscio, Borkovek, and
Ruscio (2001), anxiety is not about the specific things that are in us, the situation or incident, as a center of a source from that disorder. In generalized anxiety disorder generalized anxiety in a series of the events in everyday, and the object of this anxiety consider to think that this is something that the object cannot take control.

\section{b. Specific Phobia}

Specific Phobia is a lasting an unreasonable fear caused by the presence or thought of a specific object or no actual danger. In other words specific phobia is lasting an unreasonable fear cause by the presence or thoughts of a specific object or situation that usually poses little or no actual danger.

The writer takes some example of specific phobia based on the lyrics which is implied about it.

(17) I'm jealous of the night that

(18) I don't (do not) spend with you

In this line the speaker tells about the situation that the speaker cannot do anything with the women, the situation which is the speaker wants, the situation that he wish he can stand in with her. It is causes that the anxiety of specific phobia implied in the lyrics as a result when the speaker cannot stay right beside her. The speaker shows the sign of fear or express discomfort. In this case it can result in the word I'm jealous of the night. It is the expresses of the speaker discomfort with the situation cannot spend time with the women.

This line is still the specific phobia based on the lyrics. In this line there is sentence which is implied the unreasonable fear caused the presence and the situation. Unreasonable fear because it is hard for the speaker to say that he jealous of the situation which he cannot give the happiness for the women. In this case the women will be fine and getting happiness even though she is not with him.

\section{c. Separation Anxiety}

Separation anxiety is a psychological condition in which an individual has excessive anxiety regarding separation from place or from people to whom the individual has a strong emotional attachment. Yet the core symptoms of separation anxiety excessive and often disabling distress when faced with actual or perceive separation from major attachment figures. Separation anxiety disorder takes a dreadful toll on a person's life and 
p-ISSN 2540-8216, e-ISSN 2654-3745

https://journal.stibaiec-jakarta/ojs/index.php/jell on the lives of those around them. It is recurring distress, worrying, fear and sleep disturbances make everyday a confusing and torturous experience.

(3) It's (it is) closer than my hands have been,

(4) I'm jealous the rain

This line impliess the separation anxiety which the speaker excessive with the separation of the rain, but in this case the rain is implied the third person who is closer with the women than him as a beloved.

(18) That I don't (do not) spend with you,

(19) I'm wondering who you lay next to

(20) oh I'm jealous of the night

In short the writer takes conclusions of the separation anxiety of the speaker that he implies the scared of what will happen in the relationship between he and the women. The speaker may be suffering from the separation anxiety disorders that contributes to the feeling of anxiety. In this case the speaker must take control of what he feels where the women become far less trusting because she is subconsciously worried that someone will leave him.

\section{CONCLUSIONS}

All theories are taken with regard to the problems formulation. First, the writer defines literal meaning and figurative language of every lyric, and the second, the writer describes about the

\section{REFERENCES}

Ary, D.(1985). Introduction to Research in Education.New York

Pareja, D. (2004). Theory semantics $2^{\text {nd }}$ Edition. Jakarta: Gelora aksara Pratama

Echols, J. M and Shadily, H. 2007. Kamus Indonesia-Inggris. Jakarta: PT Gramedia Pustaka Utama.

Echols, John M and Shadily, Hasan. 2007. Kamus Inggris-Indonesia. Jakarta: PT Gramedia Pustaka Utama.

Edraswara, S. (2004). Metode penelitian sastra, epistimologi,model, dan aplikasi. Yogyakarta: Pustaka Widyatama

Groys, K. (2006). Diksi dan gaya bahasa. Jakarta: Gramedia Pustaka Utama

Guntur, H.(2009). Pengajaran gaya bahasa. Bandung: Angkasa reflection of a man who is having excessive delusion by the women and the last is the writer explain about the feeling of the speaker after being delusion by the women. The song tells about the man who feel jealousy and delusional because he lost her and he cannot stand the fact that she is giving her love to someone else, that he feel jealous all of things around her. Because they are closer than he could ever be. The writer also find some figurative language such as irony and personification in some lyrics of jealous song.

Second, the writer describes about the self defense mechanism after being not considered by the woman. In the theory of self defense mechanism the writer takes 5 types of self defense mechanism by Sigmund freud that is relate with the lyrics. The man cannot stand the fact that she is giving her love to someone else and he also feels jealous all of things around her. He tries to defense himself even they are closer than he could ever be.

Third, the writer concludes the man's feelings after being delusional by the women. Because, the man lost her intimacy and passion, the intimacy and passion is important in the relationship to build belief and trust and lasting relationship.

The lyrics of the song jealous shows about how deep the man feels jealous and delusion, when the man lost the women and went to someoneelse to share his will lost her existence. Also, the speaker shows how sorrow it is after being jealous by the woman.

Hornby. (1995). Oxford advanced leaner's dictionary of current English. London: Oxford University press.

http://publib.Boulder.ibm.com/infocenter/wmqv6 /v6r0/topic/com

http://www.answers.com/topic/answerTips http://www.forstfriends.Org/figurative.html http://www.westga.edu/ scarter/Figurative langu age 1.htm

http://sayudjberbagi.wordpress.com/2010/04/23/s tudi-kepustakaan/\#respond

Kreidler, C.W. (1998). Introducing English Semantics. USA: The Taylor \& Francis group.

Kunto, A. S, (2002). Prosedur Penelitian. Jakarta. Rimeka cipta

Kutha, N. (2009). Teori, metode, dan teknik penelitian sastra. Yogyakarta: Pustaka Pelajar 
Leech, G. (1983). Semantics. England: Penguin Book.

Long J, W.(1919). English literature: Its history and Its significance for the life of the English speaking world. USA: Ginn and Company

Lyons, J. Linguistic semantics: an introduction

Martinet, Andre. 1987. Ilmu bahasa: pengantar. Yogyakarta: Kanisius.

Oxford leaner's pocket dictionary.(1995). London: Oxford University press.

Pateda, M. (2001). Semantik leksikal. Jakarta: Renika Cipta.
Sukardi.2007.Metodologi Penelitian Pendidikan.Jakarta: Bumi Aksara

Tarigan, H. G. (1990). Pengajaran gaya bahasa. Bandung: Angkasa.

Teaching learning purpose only.(2007).

Sociolinguistics. English Education Program.

Department of Education. STAIN

Tulungagung

Wiyami.(2009). Pengantar kajian sastra. Yogyakarta: Pustaka Book Publisher 